\title{
Da utopia à distopia: a influência de aspectos culturais e históricos
}

From utopia to dystopia: influence on cultural and historical aspects

Cláudio Marcos Veloso Júnior

UEL

\section{Resumo}

Desde a publicação da obra Utopia, de Thomas More, o termo utopia tem sido usado para designar a representação de um local perfeito, sem conflitos e igualitário. A partir disso, utopia tornou-se temática presente em diversas obras literárias, principalmente no período do Renascimento. Séculos após a publicação da obra de Thomas More, surge na literatura a temática distopia, antagônica à utopia. Enquanto a utopia procura retratar um lugar perfeito, a distopia reproduz uma sociedade em caos, desigual. Essas duas temáticas aparecem na literatura devido a influências culturais e sócio-históricas. Nesse sentido, este artigo tem como objetivo fazer levantamentos de aspectos culturais e sócio-históricos que influenciaram essas temáticas na literatura.

Palavras-chave: Utopia; Distopia; Mimeses

\begin{abstract}
Since the publication of Utopia, by Thomas More's Utopia, the term utopia has been used to denote the representation of a perfect place, without conflicts and egalitarian. From this, utopia became thematic present in several literary works, mainly in the period of the Renaissance. Centuries after the publication of Thomas More's work, the thematic dystopia appears in the literature. Dystopia is antagonistic to utopia. While utopia seeks to portray a perfect place, dystopia reproduces a society in chaos, unequal. These two themes appear in the literature due to cultural and sociohistorical influences. In this sense, this article aims to survey cultural and socio-historical aspects that influenced the emergence of these themes in literature.

Keywords: Utopia; Dystopia; Mimesis
\end{abstract}


Desde A Poética, de Aristóteles, debate-se a relação da literatura com o mundo real. Aristóteles utiliza o termo "mímesis" para designar essa relação. Compagnon explica que "a mimèses seria a representação de ações humanas pela linguagem"1. As mudanças culturais e sócio-históricas ocorridas em diferentes períodos se associam às ações humanas. Nesse sentido, este estudo pretende debater como mudanças sócio-históricas e culturais influenciaram o desenvolvimento da temática da utopia e da distopia em textos literários.

Este artigo procura, primeiramente, abordar aspectos culturais e sócio-históricos para, assim, relacioná-los com obras literárias que abordam a temática da utopia e da distopia. Este estudo inicia apresentando aspectos do período histórico do Renascimento e segue até o período da Modernidade.

Segundo Hauser, o Renascimento foi um período que inova por inserir caráter científico, metódico e totalitário ${ }^{2}$ em suas obras de arte. O historiador refere-se por totalitário a intenção de criar "a aparência de mundo genuíno, autodependente, autônomo"3. A principal característica da arte do Renascimento é "a extraordinária liberdade e naturalidade de expressão" e o elemento fundamentalmente novo "é a descoberta do conceito de gênio e a ideia de que a obra de arte é criação de uma personalidade autocrática, que esta personalidade transcende a tradição, a teoria e as regras"

Hauser explica que há na Renascença um movimento universal europeu denominado de Alta Renascença, que "é absolutamente secular nas suas concepções; mesmo nas representações de assuntos religiosos, atinge o seu estilo ideal". . O historiador acrescenta que esse período possui a harmonia de ideal utópico, em que culturalmente se acreditava que poderia ser excluído todo conflito do mundo. As criações artísticas desse período "representam uma realidade elevada, enobrecida, isenta do transitório e do banal"7.

O período da Renascença foi inspirado pelas grandes navegações ocorridas no século XVI. As navegações permitiram que países da Europa descobrissem novos territórios com diversas riquezas naturais. Junto com o ideal utópico existente nesse período, as navegações geraram na população europeia a crença de que as terras descobertas seriam o local ideal para viver, uma espécie de paraíso na terra.

1 COMPAGNON, Antoine. O demônio da teoria: literatura e senso comum, 2014, p.102.

2 HAUSER, Arnold. História social da arte e da literatura, 1998, p. 358.

3 Ibidem, p. 368.

4 Ibidem, p. 364.

5 Ibidem, p. 432.

6 Ibidem, p. 464.

7 Ibidem, p. 466. 
Esses aspectos históricos influenciam para que se manifeste na literatura o tema do descobrimento de um novo mundo. Auerbach ressalta que "este é um dos grandes temas do Renascimento e dos dois séculos seguintes" e de grande atualidade para aquela época, além de ser "um dos motivos que serviram de alavanca para a revolução política, religiosa, econômica e filosófica"s.

Diversas obras literárias têm como principal temática a representação de um mundo com um ideal de perfeição, em que todo conflito é extinto. Exemplo disso é a Utopia, de Thomas More. Essa obra é datada no ano de 1516. Sobre essa obra, Baczko expõe que ela é:

\begin{abstract}
uma obra particularmente densa, dotada de uma estrutura extremamente complexa. Impossível resumi-la sem a mutilar. É indispensável, todavia, fazer uma breve apresentação do livro afim de compreender a invenção de um paradigma destinado a tão longo futuro?.
\end{abstract}

Nessa obra, Thomas Morus narra a descrição feita pelo personagem Rafael Hitlodeu a respeito de uma sociedade em que viveu por cinco anos, situada em uma ilha com o nome de Utopia. Essa obra é totalmente descritiva e sua intenção é configurar Utopia como um local ideal, onde os indivíduos, que lá habitam, vivem de forma igualitária e em harmonia. A igualdade está presente em todos os aspectos sociais. O território de Utopia é dividido em cinquenta e quatro províncias que regem uma mesma legislação, falam a mesma língua e possuem o espaço do território semelhante umas das outras.

A igualdade está presente principalmente na divisão das funções sociais. O trabalho com agricultura é de conhecimento de todos os utopianos, assim como o ofício de pedreiro, ferreiro e carpinteiro. O trabalho agrícola é de responsabilidade de trinta famílias que, no período de dois em dois anos, revezam-se para que todos assim, de forma igualitária, realizem a mesma função. As demais famílias responsabilizam-se em exercer as outras funções. A produção de alimentos é totalmente controlada para que nunca haja uma demanda a mais ou a menos e é distribuída a todos os habitantes da ilha.

Outro aspecto que demonstra a igualdade nessa ilha é o fato de os indivíduos utilizarem vestimentas que se diferem unicamente entre o vestuário masculino e o feminino. A intenção do uso de modelos únicos de vestimentas é para demonstrar que, por viverem de forma igualitária e em harmonia, os habitantes dessa sociedade não sentem a necessidade de terem mais riquezas que os outros.

8 AUERBACH, Erich. Mimesis: a representação da realidade na literatura, 2013, p. 235.

9 BACZKO, Bronislaw. "Utopia", Enciclopédia Einaudi,1989, p. 68. 
Backzo reflete sobre a obra de Thomas More:

[Ela] que dura já há séculos se quer não faz mais do que reforçar o carácter paradigmático deste 'verdadeiro livro de ouro'. Paradigma literário em primeiro lugar: narrativa de uma viagem imaginária ao cabo da qual o narrador descobre uma Cidade até então desconhecida e que distingue por instituições de que o narrador faz uma pormenorizada descrição. Paradigma específico do imaginário social: representação de uma sociedade radicalmente outra, situada no algures definido por um espaço-tempo imaginário ${ }^{10}$.

Além disso, Backzo debate a respeito do paradigma em referência ao título Utopia. Para ele, há duas hipóteses as quais o nome faz referência:

O que se passa então com este vocábulo-chave de todo o texto? Designa ele a U-topia, terra de nenhures, terra que não existe em parte alguma, ou designa então Eu-topia, isto é, o melhor país, superior mesmo àquele que Platão imaginara? Ou ambas as coisas ao mesmo tempo: a melhor comunidade política, sem dúvida imaginável pois que disso o texto é prova, mas que não existe em parte alguma, a não ser no imaginário que se abre perante o saber e que este elabora? ${ }^{11}$

Por influência dessa obra, o termo utopia começou a ser inserido nos dicionários e enciclopédias para designar a representação de uma civilização ideal. A influência perdura até hoje, tanto que o Grande Dicionário Etimológico Prosódico cita que a palavra utopia tem sua base do grego "outopos" correspondendo "ou" a não e "topos" a lugar, dessa forma, a derivação "utópico" representa um lugar imaginário ${ }^{12}$ e a Enciclopédia Barsa explica que a utopia representa um "sistema de pensamento político que espera ou promete para o futuro um estado de felicidade geral, graças a uma nova organização da sociedade, das instituições políticas e das relações econômicas"13.

Massaud Moisés confirma Thomas More como o criador do termo de utopia e explica que a intenção do autor era fazer "trocadilho com eutopia, lugar onde tudo está bem" ${ }^{14}$ e:

desfaz a parelha espaço/tempo, de modo a situar-se num eterno presente ou num tempo inexistente, ou que não conta, em suma, numa ucronia. E mesmo quando

10 Ibidem, p. 12.

11 Ibidem, p. 13.

12 UTOPIA, Grande Dicionário Etimológico Prosódico, 1967, p.635.

13 UTOPIA, Enciclopédia Barsa, 1973, p. 414.

14 MOISÉS, M. Dicionário de termos literários, 2004, p. 458. 
a fantasia do escritor se projeta no futuro, é sempre da perspectiva do presente ${ }^{15}$.

Nesse contexto, Backzo reflete que o conceito de utopia, mesmo que ficcionalmente, surge como uma alternativa para que ocorra uma transformação da natureza pela cultura e, assim, as sociedades obtenham a legitimidade a que o termo faz referência ${ }^{16}$. O estudioso expõe ainda que Utopia é um dos "modelos racionais de sociedade onde a felicidade se realizou" e explica:

No início do século XVI, esta operação de 'desencantar' a ordem social tradicional e as suas representações estava já em fase adiantada e não se efectuava, apenas,através da invenção de construções racionais de comunidades perfeitas e auto-reguladas. Várias aproximações seriam necessárias fazer entre a invenção do paradigma utópico e outros agentes de mudança que actuavam na mesma altura, no seio da «modernidade», implicando uma transformação do olhar sobre o mundo e, designadamente, sobre o social ${ }^{17}$.

Influenciados pelo contexto histórico, outros autores irão explorar a representação de um novo mundo. Dezesseis anos depois da publicação da obra de Thomas More, o escritor Rabelais insere em sua obra Gargatua e Pantagruel a descrição de um novo mundo e utiliza o tempo utopia para designá-lo. Auerbach ressalta as semelhanças entra a obra de Rabelais e a de Morus:

Rabelais chamou o país dos gigantes inicialmente de Utopia, um nome que pediu emprestado da obra de Thomas Morus, aparecida dezesseis ano antes, homem ao qual, dentre todos os seus contemporâneos, talvez mais devesse e que foi um do primeiros a empregar o motivo do país na forma mais modelar-reformista acima descrita. Não é só o nome: o país Gargantua e Pantagruel, como as suas formas de vida política, religiosa e pedagógica não só se chama, mas é Utopia: um país longínquo, ainda não bem descoberto, um país que, como o de Thomas Morus, fica em algum lugar do longínquo Oriente ${ }^{18}$.

A representação de um lugar com caráter utópico está presente também em Os Lusíadas, de Luís Vaz de Camões. Essa obra epopeica foi publicada pela primeira vez em 1572. O local utópico encontra-se nessa epopeia no canto IX, a partir da estrofe $52^{19}$. A estrofe 52 revela

15 Ibidem, p. 459.

16 BACZKO, Bronislaw. "Utopia”. Enciclopédia Einaudi, 1989, p. 13-14.

17 Ibidem, p. 14.

18 AUERBACH, Erich. Mimesis: a representação da realidade na literatura, 2013, p. 236.

19 CAMÕES, Luís Vaz. Os Lusíadas, p. 232-235. 
que esse lugar é uma ilha e, por predisposição de Vênus, navegantes portugueses tiveram seus caminhos direcionados até lá. A ilha é adjetivada, no canto 54, como alegre e deleitosa. Os cantos 55 e 59 ilustram, nessa ilha, a presença de um vale ameno com claras águas, que conforme narração é "tão bela quanto pode imaginar-se" 20 e uma grande quantidade de árvores com diversos frutos, como laranjas, limões, cerejas, romãs, que são alguns deles adjetivados por lindo, fermosos ${ }^{21}$. Revela-se na estrofe 68 a 70 a presença de seres nessa ilha. Estes seres tratamse de ninfas. Na narrativa, os navegantes portugueses entram em contato com elas.

O caráter utópico é criado pelos diversos adjetivos positivos utilizados para descrever esse lugar. O próprio narrador, no canto 57, utiliza o termo paraíso para designá-lo: "Pêra onde é posto o etéreo Paraíso"22. É de relevância reiterar que o local escolhido para ser ilustrado, o lugar utópico, é uma ilha, assim como na obra de Thomas Morus. Com isso, a escolha de descrever a utopia em uma ilha ocorre devido à intenção de se inserir na obra a temática do descobrimento de um novo mundo, visto que Os Lusíadas inclui-se no Renascimento.

A literatura brasileira também é influenciada por esse contexto histórico. Gomes expõe:

Aspectos significativos do Barroquismo literário brasileiro de seiscentos, sobre serem rebentos, enfezados embora, da literatura de expansão e descoberta do quinhentismo português, são as obras de exaltação ufanista da nova terra - coisas, homens e costumes - e os livros de descrição de viagens, naufrágios e roteiros de exploração marítima e terrestre ${ }^{23}$.

Períodos adiante, há a publicação de As viagens de Gulliver, de Jonathan Swift, expondo uma viagem a novos mundos. Dois séculos após a publicação de Utopia, a obra Swift começa a desfazer o caráter utópico. A visão renascentista de um novo mundo com caráter perfeito começa a ser desfeito. Para respaldar em sua obra a quebra do caráter perfeito de um novo mundo, Swift narra a viagem de Gulliver para três novos mundos em que todos eles possuem conflitos. Entretanto, procura manter o caráter utópico desses lugares.Entretanto analisando a enunciação percebe-se que esses países estão norteados de conflitos internos e externos. Swift, ao expor esses três lugares com conflitos, evidencia que independente do lugar que o protagonista for, haverá atritos que impossibilitarão a existência de um caráter perfeito a esses lugares.

Por meio da paródia, Swift questiona valores sociais. Um deles é relacionado ao caráter

20 Ibidem, p. 232.

21 Ibidem, p. 232-233.

22 Ibidem, p. 233.

23 GOMES, Eugênio. "Botelho de Oliveira, Nuno Marques Pereira". IN: COUTINHO, Afrânio. A Literatura no Brasil, 1968, p. 255. 
científico existente no Renascimento. O autor redargui que muitas das descobertas científicas não são úteis para o meio social, sendo, portanto,supérfluas. Swift ainda expõe que a origem de muitos conflitos sociais é por motivos fúteis:

\begin{abstract}
Duas grandes potências que, como ia eu dizer-vos, andam empenhadas, há mais de 36 luas, numa guerra encarniçadíssima, cujo móvel foi o seguinte reconhece-se universalmente que a maneira primitiva de quebrar ovos para comê-los consistia em quebrá-los pela ponta mais grossa; mas ao avô da Sua Majestade, quando menino, numa ocasião em que se dispunha a comer um ovo e quebrá-lo consoante o hábito antigo, sucedeu-lhe cortar um dedo; pelo que o imperador, seu pai, saiu com um edito em que ordenava a todos os seus súditos, sob grandes penalidades, quebrarem os seus ovos pela ponta mais fina. Ressentiu-se por tanta maneira o povo dessa lei que, referem as nossas histórias, seis rebeliões estalaram por causa diss ${ }^{24}$.
\end{abstract}

Por mais que sejam apresentados conflitos, não se pode considerar a obra As viagens de Gulliver uma distopia. Ela trata-se de uma falsa utopia, ou seja, um mundo em que só há igualdade nas aparências, visto que o local descrito não atinge um ideal de perfeição e felicidade total. As distopias são mais frequentes no início do século XX. O termo distopia:

\footnotetext{
caracteriza-se pela antevisão de um lugar imaginário onde reinaria o caos, a desordem, a anarquia, a tirania, ao contrário do paraíso cristão ou dos mitos de felicidades eterna, cidade do sol, 'shangri-la', eldorado, xanadu, terra de maravilhas, arcádia, país de cocanha ${ }^{25}$.
}

Sendo assim, a distopia é o contrário de utopia. Enquanto a utopia expõe o lugar perfeito, feliz, pacífico eigualitário , a distopia procura apresentar um cenário em que reinam o caos, o medo, a desigualdade, a alienação. Destacam-se entre as distopias: Admirável Mundo Novo, de Aldous Huxley; Revolução dos Bichos e 1984, ambos de George Orwell. Essas obras tratam-se de distopias não por serem marcadas apenas por conflitos, mas também por reinar a desigualdade. Além disso, a felicidade dentro dessas narrativas é simulada ou inexistente. Todas essas obras foram influenciadas pelo contexto histórico do século XX e por aspectos culturais existentes nesse período.

O século XX foi marcado por inovações tecnológicas, conflitos em proporção mundial e crises financeiras que culminaram no aparecimento de Estados totalitários. Hobsbawm coloca que "a economia industrial moderna foi construída com base em inovação tecnológica

24 SWIFT, Jonathan. Viagens de Gulliver, 1998, p. 48.

25 MOISÉS, M. Dicionário de termos literários, 2004, p. 129. 
constante" ${ }^{26}$. Dentre as principais inovações, foi a inserção do rádio nos lares que:

transformava a vida dos pobres, e sobretudo das mulheres pobres presas ao lar, como nada fizera antes. Trazia o mundo à sua fala. Daí em diante, os mais solitários não precisavam mais ficar inteiramente sós. E toda a gama do que podia ser dito, cantado, tocado ou de outro modo expresso em som estava agora ao alcance deles ${ }^{27}$.

Devido a essas inovações, Buck-Morssexpõe que Walter Benjamin considera esse período uma época dominada pela auto-alienação. Esse aspecto "atingiu uma tal magnitude que é capaz de experimentar a sua própria destruição . Assim também com a estetização da política, que tem sido levada a cabo pelo fascismo. O comunismo responde com a politização da arte ${ }^{28}$.

Outro fator que fortaleceu a auto-alienação nesse período foi a proliferação do uso de drogas. Buck-Morss coloca que "o vício em drogas é característico da modernidade"29. Os conflitos em proporção mundial desse período - primeira e segunda guerra mundial - passaram a ser:

'guerras populares', tanto porque os civis e a vida civil se tornaram os alvos estratégicos certos, e às vezes principais, quanto porque em guerras democráticas, como na política democrática, os adversários são naturalmente demonizados para fazê-los devidamente odiosos ou pelo menos desprezíveis ${ }^{30}$.

Esse fato culminou em um remapeamento territorial após o fim da Primeira Guerra Mundial. "O princípio básico de reordenação do mapa era criar Estados-nação étnicolinguístico, segundo a crença que as nações tinham o "direito de autodeterminação"' ${ }^{1}$. Ainda sobre esse período, Hobsbawm expõe que "houve uma crise na produção básica, tanto de alimentos como de matérias-primas, porque os preços, não mais mantidos pela formação de estoques como antes, entraram em queda livre"32. O historiador complementa: "A crise afetou as várias partes do mundo de maneira e em graus diferentes, mas afetou a todas elas, fossem quais fossem suas configurações políticas, sociais e econômicas ${ }^{33}$ ".

26 HOBSBAWM, Eric. Era dos extremos: o breve século XX 1914-1991, 1996, p. 55.

27 Ibidem, p. 194.

28 BUCK-MORS, Susan. "Estética e Anestética: o 'Ensaio sobre a obra de arte' de Walter Benjamin reconsiderado". Travessia, 1996, p. 12.

29 Ibidem, p. 26.

30 HOBSBAWM, Eric. Era dos extremos: o breve século XX 1914-1991, 1996, p. 56.

31 Ibidem, p. 38.

32 Ibidem, p. 96.

33 Ibidem, p. 19. 
Essa crise foi um dos principais responsáveis para o aparecimento de Estados totalitários. Hanna Arendt afirma que há

apenas duas formas autênticas de domínio totalitário: a ditadura do nacional-socialismo, a partir de 1938, e a ditadura bolchevista, a partir de 1930. Essas duas formas de domínio diferem basicamente de outros tipos de governo ditatorial, despótico ou tirânico ${ }^{34}$.

A ditadura do nacional-socialismo foi marcada pelo regime nazista, comandado por Hitler, e pelo regime fascista, liderado por Mussolini. A ditadura bolchevista na Rússia consolidou-se em 1930, entretanto a sua revolução deu-se início em 1917 e teve, primeiramente, como líder Lenin. Anos após o início da revolução, Lenin foi deposto do cargo de líder, ficando em seu lugar Stálin. Essa revolução se fundamentou principalmente nos ideais utópicos expostos por Marx e Engels em Ideologia Alemã e no Manifesto Comunista. Ambos os escritos propunham que uma classe revolucionária, que no caso é a proletária, deveria tomar o poder da classe dominante, que no caso é a burguesia, e consolidar uma sociedade onde se extinguisse "a dominação de todas as classes abolindo as próprias classes" 35 .

Uma das principais armas para o controle social do regime totalitário foi a propaganda. Por meio da propaganda, o Estado totalitário dissimula informações com o intuito de fazer seus cidadãos acreditarem e aceitarem as informações que são passadas. Sobre isso, Arendt afirma:

\footnotetext{
a propaganda totalitária aperfeiçoa as técnicas da propaganda de massa, mas não lhe inventa os temas. Estes foram preparados pelos cinquenta anos de imperialismo e desintegração do Estado nacional, quando a ralé adentrou o cenário da política europeia $^{36}$.
}

Na Rússia bolchevista: "Stálin fazia questão de apresentar ao mundo a imagem de um líder diligente, que se contentava com um mínimo de bens materiais" ${ }^{\prime 37}$. A respeito do terror e da propaganda, Arendt chama a atenção para não se considerar a propaganda e o terror como dois elementos da mesma face, pois isso é:

34 ARENDT, Hannah. Origem do totalitarismo: antissemitismo, imperialismo, totalitarismo, 2013, p. 558-559.

35 MARX, Karl. ENGELS, Friedrich. Manifesto Comunista. Trad. Álvaro Pina. São Paulo: Boitempo Editorial, 4. ed., 2005.

36 ARENDT, Hannah. Origem do totalitarismo: antissemitismo, imperialismo, totalitarismo, 2013, p. 484.

37 TOLSTOY, Nikolai. A guerra secreta de Stálin, 1981, p. 49. 
[...] verdadeiro só em parte. Quando o totalitarismo detém o controle absoluto, substitui a propaganda pela doutrinação e emprega a violência mais para assustar o povo - o que é só feito nos estágios iniciais, quando ainda existe oposição política -, mas para dar realidade às suas doutrinas ideológicas e suas maneiras utilitárias $^{38}$.

Alicerçado nesse contexto, as obras distópicas exploram esses diversos aspectos do século XX. A primeira obra com essa temática escrita neste século a ser analisada é o romance Admirável Mundo Novo, de Aldous Huxley.

O romance Admirável Mundo Novo, publicado em 1932, propõe em seu enredo uma sociedade futurista, aparentemente, apenas com boas qualidades, sem conflitos e igualitária, em que os indivíduos são guiados a aceitarem as regras sociais que lhes são impostas desde o nascimento. O contexto histórico do início do século XX está presente até nas escolhas dos nomes dos personagens. Ao nomear um personagem de Bernard Marx, o autor está fazendo alusão a Karl Marx. Ao nomear outra personagem de Lenina, a obra faz alusão à figura do líder bolchevista Lenin.

Assim como propõe os escritos de Marx e Engels, a sociedade de Admirável Mundo Novo não possui diferenças de classes, mas há uma divisão de trabalho com base nas diferenças físicas. Essas diferenças determinam a que casta cada sujeito pertence. Aquele que faz parte de uma casta considerada superior (Alpha) tem mais privilégios do que aquele que se insere em uma casta inferior (Beta; Gama; Delta). Os que fazem parte da casta mais baixa (Ípsilon) não possuem nenhum privilégio, restando a eles só a função de trabalhar. A existência dessa desigualdade de castas faz com que esse romance não seja considerado uma utopia. Huxley ao inserir castas em seu romance está o aproximando-o do que acontecia na Rússia durante a ditadura bolchevista, visto que, como relata Benjamin, a Rússia daquela época não era "apenas um Estado de classes, mas, antes, de castas. Um Estado de castas - isso significa que o valor social do cidadão não é definido pelo lado exterior representativo de sua existência - como vestuário e moradia -, mas unicamente pela relação com o partido"39.

Não somente Marx, o nome de Ford e Freud, figuras importantes nesse período histórico, estão presentes na narrativa de Huxley:

Nosso Ford - ou nosso Freud, como, por alguma razão inescrutável, preferia ser chamado sempre que tratava de assuntos psicológicos -, nosso Freud foi o primeiro a revelar os perigos espantosos da vida familiar. O mundo estava cheio de pais - em

38 ARENDT, Hannah. Origem do totalitarismo: antissemitismo, imperialismo, totalitarismo, 2013, p. 474 .

39 BENJAMIN, Walter. Imagens do Pensamento. Obras escolbidas II: Rua de mão única, 2000, p. 173. 
consequência, cheio de aflição, cheio de mães ${ }^{40}$.

Em Admirável Mundo Novo, a figura Ford é igualada a de um Deus. Baker ressalta a relação da deificação de Ford na obra Admirável Mundo Novo com a figura do industrial norte-americano:

The deification of Henry Ford within a kind of secular religion underscores the
centrality of Taylorism in Huxley's vision of a technocracy where biology is an in-
strument of economic policy. Ford, then, as the World State's personification of
triumphant technology, requires some brief discussion. Between 1910 and 1920
Henry Ford's name had become synonymous with technical advances in industrial
production. The appearance of the Model T in 1908 and the seemingly insatiable
demand for Ford's product led to a series of innovations in production methods. ${ }^{41}{ }^{42}$

Nesse mesmo panorama, Baker destaca a influência de Sigmund Freud na obra de Huxley: "In his social novels of the twenties Huxley made extensive use of Freudian ideas populating his narrative swith characters twisted and warped by neurosis and, occasionally, by psychoticfears and anxieties” ${ }^{` 344}$.

Outro ponto dessa obra que o iguala com o seu contexto histórico é presença do rádio e das propagandas. Na sociedade de Admirável Mundo Novo, as regras sociais são expostas através do rádio. Os discursos proferidos pelo rádio procuram demonstrar os pontos positivos da sociedade, criando a aparência de só existirem boas qualidades. Essa doutrinação tem a intenção de fazer com que o indivíduo tenha a sensação de felicidade por fazer parte da casta que ele é destinado a ser para, assim, aceitar as regras sociais com mais passividade.Fundamenta-se assim uma auto-alienação:

As crianças Alfas vestem roupas cinzentas. Elas trabalham muito mais do que nós porque são formidavelmente inteligentes. Francamente, estou contentíssimo de ser

40 HUXLEY, Aldous. Admirável Mundo Novo, 2009, p. 78.

41 "A deificação de Henry Ford dentro do tipo de religião secular ressalta a centralidade do taylorismo na visão de Huxley de uma tecnocracia onde a biologia é um instrumento de política econômica. Ford, então, como a personificação da tecnologia triunfante do Estado Mundial, requer uma breve discussão. Entre 1910 e 1920, o nome de Henry Ford tornou-se sinônimo de avanços técnicos na produção industrial. O surgimento do Modelo T em 1908 e a aparentemente insaciável demanda pelo produto da Ford levaram a uma série de inovações nos métodos de produção" (Tradução própria).

42 BAKER, Robert. Brave New World: history, Science and Dystopia, 1990, p. 83.

43 "Em seus romances sociais dos anos vinte, Huxley fez uso extensivo das ideias freudianas que povoavam suas narrativas com personagens distorcidos e distorcidos pela neurose e, ocasionalmente, por medos e ansiedades psicóticas" (Tradução própria).

44 BAKER, Robert. Brave New World: history, Science and Dystopia, 1990, p. 88. 
um Beta, porque não trabalho tanto. E, além disso, somos muito superiores aos Gamas e aos Deltas. Os Gamas são broncos. Eles se vestem de verde e as crianças Deltas se vestem de cáqui. Oh, não, não quero brincar com crianças Deltas. E os Ípsilons são ainda piores ${ }^{45}$.

Nesse intento de proporcionar a felicidade ao indivíduo, insere-se o uso de uma substância química nomeada "soma". Ao depararem com algum conflito, os cidadãos ingerem o soma para então poder ter a sensação de prazer, o que faz referência ao uso de drogas que é algo cultural no século XX.

Conclui-se, nessa perspectiva, que a felicidade em Admirável Mundo Novo é simulada, já que a felicidade depende de mecanismos para ser efetiva. É por meio desses mecanismos que essa sociedade mantém-se sem conflitos. A ausência de violência pode fazer com que se questione se a obra de Huxley é devidamente uma distopia. Entretanto, pode-se afirmar que é uma distopia, apesar de a violência não ser física, ela está presente durante a imposição de diferenças de castas e a privação de toda a liberdade do indivíduo.

O romance A Revolução dos bichos, de George Orwell, também procura explorar o cenário da Revolução Bolchevista. A narrativa da obra se desenvolve em uma fazenda em que os animais se revoltam contra o seu dono e tomam o controle do lugar, ou seja, assim como na Revolução Bolchevique, a classe proletária toma o poder da classe dominante. Por serem os responsáveis em produzir a mão de obra, os animais representam a classe proletária, enquanto que o dono da fazenda, que no caso é um homem, representa a burguesia por ser o dono do meio de produção e o explorador. Quem propõe a revolução é um porco chamado de Major. É ele que evidencia o homem como dominador:

O homem é a única criatura que consome sem produzir. Não dá leite, não põe ovos, é fraco demais para puxar arado, não corre o que dê para pegar uma lebre. Mesmo assim, é o senhor de todos os animais. Põe-nos a mourejar, dá-nos de volta o mínimo para evitar a inanição e fica com o restante ${ }^{46}$.

Quem planeja e aplica a revolução são os porcos Bola-de-Neve e Napoleão:

Haviam organizado os ensinamentos do Major num sistema de pensamento a que deram o nome de Animalismo. Várias noites por semana, depois que Jones dormia, faziam reuniões secretas no celeiro e expunham aos outros os princípios do Animalismo ${ }^{47}$.

45 HUXLEY, Aldous. Admirável Mundo Novo, 2009, p. 62.

46 ORWELL, George. A revolução dos bichos, 2007, p. 12.

47 Ibidem, p. 19. 
Nessa perspectiva, há uma associação do Major com Karl Marx e do Bola-de-Neve e Napoleão com Lenin e Stálin. O termo Animalismo refere-se ao Comunismo. Essa ligação fica mais evidente ao Napoleão destituir Bola-de-Neve de seu poder e expulsá-lo da fazenda, da mesma forma que Stálin fez com Lênin:

\begin{abstract}
Houve um terrível latido do lado de fora, e nove cães enormes usando colheitas tachonadas de bronze entraram aos saltos no celeiro. Jogaram-se sobre Bola-de-Neve, que saltou do lugar onde estava mal a tempo de escapar àquelas presas. Num instante, zuniu porta afora com os cães em seu encalço. Espantados e aterrorizados demais para falar, os bichos amontoaram-se na porta para observar a caçada. Bola-de-Neve corria pelo campo em direção à estrada, como só um porco sabe correr, mas os cachorros se aproximavam. [...] Napoleão, com os cães e segui-lo, subiu para o estrado de onde o Major fizera seu discurso. Anunciou que daquele momento em diante terminariam as reuniões aos domingos de manhã $\tilde{a}^{48}$.
\end{abstract}

O que torna a obra A revolução dos bichos uma distopia é o fato de ter sido criado, após a revolução dos animais, um Estado totalitário dentro da fazenda, onde os indivíduos não possuem liberdade.O terror é utilizado como uma forma de controle social e de alienação dos indivíduos, imperando, dessa forma, o medo e a desigualdade. A existência do terror como forma de controle social é outro fato que relaciona esse romance com o ocorrido após a Revolução bolchevique, visto que Lênin, ao assumir o poder na Rússia, "advogou o uso máximo do terror contra todos que eram, ou podiam ser, contrários às suas ideias" ${ }^{49}$.

A obra 1984, publicada em 1948, de George Orwell, também contempla o contexto histórico e os aspectos culturais em sua narrativa. 1984 configura em seu enredo um Estado totalitário dominado pela repreensão em forma de terror e a vigilância. Ao reprimir e vigiar, o Estado obriga os indivíduos a aceitarem as regras sociais e a se contentarem com a sua forma de vida. O uso do terror era comum nos estados totalitários. Arendt explica que:

a diferença fundamental entre as ditaduras modernas e as tiranias do passado está no uso do terror não como meio de extermínio e amedrontamento dos oponentes, mas como instrumento corriqueiro para governar as massas perfeitamente obedientes. O terror, como conhecemos hoje, ataca sem provocação preliminar, e suas vítimas são inocentes até mesmo no ponto de vista do perseguidor ${ }^{50}$.

O estado do de 1984 é controlado por um único partido. O líder desse partido é chamado

48 Ibidem, p. 48.

49 TOLSTOY, Nikolai. A guerra secreta de Stálin, 1981, p. 72.

50 ARENDT, Hannah. Origem do totalitarismo: antissemitismo, imperialismo, totalitarismo, 2013, p.

29.

Universidade Federal de Santa Catarina - 2o Semestre de 2018 
de "Grande Irmão". Essa conjuntura se iguala ao que aconteceu na Rússia após a Revolução Bolchevique. Arendt explica que a Rússia foi governada por um único partido e que seu objetivo principal não era:

apenas apoderar-se da administração do governo, mas sim, através do preenchimento de todos os postos com membros do partido, atingir uma completa amálgama de Estado e partido, de sorte que, após a tomada do poder, o partido se torna uma espécie de organização de propaganda do governo ${ }^{51}$.

A imagem do Grande Irmão está presente em painéis, cartazes em estabelecimento públicos, o que a torna uma figura emblemática. O Grande Irmão é visto nessa sociedade como um herói. É dado a ele o atributo de salvador da pátria. Esses fatos fazem alusão à imagem de Lenin na Rússia que, conforme relata Walter Benjamin, era tão culturalmente emblemática a ponto dos locais de trabalhos estarem "impregnados de emblemas soviéticos e cabeças de Lenin" 52 . Culturalmente, atribuíram à figura de Stalin "características heroicas - bondade, onisciência, modéstia, imensa e incansável capacidade de trabalho" ${ }_{33}$.

Arendt expõe que o objetivo principal de um estado totalitário é o de domínio total do mundo ${ }^{54}$. Na obra de Orwell, há um remapeamento de território em que três grandes potências dominavam: a Oceânia, a Eurásia e a Lestásia. Essas três potências guerreavam para ter o domínio total do mundo. Para tal intento, era comum a aliança entre uma potência e outra, embora as alianças, frequentemente, se alternassem:

\begin{abstract}
A Oceania sempre estava em guerra com a Lestásia: a Oceania sempre estivera em guerra com a Lestásia. Boa parte da literatura política dos últimos cinco anos se tornara completamente obsoleta. Relatórios e publicações de todo tipo, jornais, livros, panfletos, filmes, trilhas sonoras, fotografias - tudo tinha de ser corrigido à velocidade da luz. Embora jamais se emitissem instruções precisas, sabia-se que os chefes do Departamento pretendiam que em uma semana já não existissem em lugar nenhum referências à guerra com a Eurásia ou à a aliança com a Lestásia ${ }^{55}$.
\end{abstract}

Hobsbawm expõe que, na década de 30, houve uma aliança entre a Rússia e os Estados Unidos para combater a ofensiva Alemã na Europa, criando assim três frentes durante esse

51 Ibidem,p. 559.

52 BENJAMIN, Walter. Imagens do Pensamento. Obras escolbidas II: Rua de mão única, 2000, p. 179.

53 TOLSTOY, Nikolai. A guerra secreta de Stálin, 1981, p. 34.

54 ARENDT, Hannah. Origem do totalitarismo: antissemitismo, imperialismo, totalitarismo, 2013, p. 563.

55 ORWELL, George. 1984, 2009, p. 217. 
período: Os Estados Unidos, a Rússia e a Alemanha. O próprio historiador expõe que a aliança entre a Rússia e os Estados Unidos se deteriorou e iniciou-se uma disputa entre os dois ${ }^{56}$.

A vigilância ocorre em 1984 de forma que os próprios cidadãos são osresponsáveis por vigiar e denunciar atividades dos demais sujeitos que estão em desacordo com as ideologias do partido. Esse fato se iguala novamente com a ditadura bolchevista, pois na Rússia bolchevista os cidadãos também tinham o papel de um vigiar o outro -- "todo mundo, de certa forma, é o agent provocateur de todo mundo" ${ }^{\text {. }}$. Na sociedade de 1984, não há leis. Os crimes nessa sociedade são determinados de acordo com o interesse do partido, assim como os regimes totalitaristas do século XX em que "não existia outra lei a não ser aquela que a liderança do Partido considerasse como tal" ${ }^{\text {". }}$. Os indivíduos que os cometem são punidos com a tortura da mesma forma que ocorria na Rússia.

Assim como em Admirável Mundo Novo, o rádio, em 1984, é utilizado para disseminar propagandas. As informações difundidas no rádio sempre têm caráter positivo. O rádio também é utilizado para adulterar fatos do passado, ou seja, por meio do rádio, eram expostos fatos do passado que nunca ocorreram para assim haver um controle sobre a história. Nessa perspectiva, a obra de Orwell novamente está se relacionando com o contexto histórico do século XX, visto que, como coloca Hobsbawm, "a destruição do passado - ou melhor, dos mecanismos sociais que vinculam nossa experiência pessoal à das gerações passadas - é um dos fenômenos mais característicos e lúgubres do final do século XX"59.

Por expor uma sociedade na qual reinam o caos, o medo, a desigualdade, a alienação, 1984 é uma distopia concreta. Ao Orwell coube contemplar vários aspectos culturais e históricos do início do século XX em uma sociedade distópica, ele está criando uma alegoria do contexto histórico em que a obra foi escrita e, ao fazer referência à Rússia bolchevista, ele está demonstrando que a Rússia daquele período trata-se uma sociedade distópica.

Essas análises confirmam a influência do contexto sócio-histórico para a projeção de sociedades utópicas e distópicas na literatura. A alteração entre a temática da utopia para a distopia ocorreu devido à mudança do ponto de vista e da perspectiva que dada sociedade possuía em relação ao mundo. Durante o Renascimento, a sociedade tinha a esperança de encontrar um lugar perfeito. Utopia é o nome dado a temática que representa esse pensamento social na literatura. A utopia é assim a representação desse lugar perfeito. Com o decorrer dos séculos, o mito ufanista foi-se desfazendo e a sociedade observou que a ideia de um mundo

56 HOBSBAWM, Eric. Era dos extremos: o breve século XX 1914-1991, 1996, p. 145.

57 TOLSTOY, Nikolai. A guerra secreta de Stálin, 1981, p. 552.

58 Ibidem, p. 20.

59 HOBSBAWM, Eric. Era dos extremos: o breve século XX 1914-1991, 1996, p. 13. 
perfeito era inconcebível. Há nesse contexto uma decepção e desencanto em relação ao mundo. A sociedade começa a prognosticar que o futuro do mundo seria a base do caos, da desigualdade, o ideal perfeito não é mais imaginado. Nesse contexto, abre-se espaço para a representação de distopias na literatura.

\section{Referências}

ARENDT, Hannah. Origem do totalitarismo: antissemitismo, imperialismo, totalitarismo. Trad. Roberto Raposo. São Paulo: Companhia de Bolso, 2013.

AUERBACH, Erich. Mimesis: a representação da realidade na literatura. São Paulo: Perspectiva, 6. ed., 2013.

BACZKO, Bronislaw. "Utopia".In: p.67-101

Enciclopédia Einaudi. Vol. 5. Lisboa: IN-CM, 1989.

BAKER, Robert. Brave New World: history, Science and Dystopia. Boston: Twayne Publishers, 1990.

BENJAMIN, Walter. Imagens do Pensamento. In: . Obras escolbidas II: Rua de mão única. São Paulo: Brasiliense, 2000.

BUCK-MORS, Susan. "Estética e Anestética: o 'Ensaio sobre a obra de arte' de Walter Benjamin reconsiderado". In: Travessia. Ilha de Santa Catarina: UFSC, n. 33, 1996. p.11-41.

CAMÕES, Luís Vaz. Os Lusíadas. São Paulo: Martin Claret, 2. ed., 2009.

COMPAGNON, Antoine. O demônio da teoria: literatura e senso comum. Belo Horizonte: Editora UFMG. $2^{\mathrm{a}}$ ed., 2014.

Enciclopédia Barsa. Rio de Janeiro: Encyclipaedia Britannica Editores, v. 13, 10. ed., 1973.

Grande dicionário etimológico-prosódico da língua portuguêsa. São Paulo: Editora Saraiva, v.8, 1967.

GOMES, Eugênio. "Botelho de Oliveira, Nuno Marques Pereira". IN: COUTINHO, Afrânio. A Literatura no Brasil. Rio de Janeiro: Editoral Sul Americas. 2. ed., 1968. p.255-283.

HAUSER, Arnold. História social da arte e da literatura. Trad. Álvaro Cabral. São Paulo: Martins Fontes, 1998.

HOBSBAWM, Eric. Era dos extremos: o breve século XX 1914-1991. Trad. Marcos Santarrita. São Paulo: Companhia das Letras, 2. ed., 1996.

HUXLEY, Aldous. Admirável Mundo Novo. Trad. Lino Vallandro e Vidal Serrano. São Paulo: Globo, 2. ed., 2009.

MARX, Karl; ENGELS, Friedrich. A ideologia Alemã. São Paulo: Martins Fontes, 1998.

Disponível em: < http://www.usp.br/cje/anexos/pierre/aideologiaalema_karlmarx_e_engels. pdf:. Acesso em: 13 out. 2014.

MARX, Karl; ENGELS, Friedrich. Manifesto Comunista. Trad. Álvaro Pina. São Paulo: Boitempo Editorial, 4. ed., 2005. Disponível em: < http://www.uel.br/grupo-pesquisa/socreligioes/pages/ arquivos/MARX;\%20ENGELS\%20-\%20Manifesto\%20do\%20Partido\%20Comunista.pdf:. Acesso 
em: 19 jul.2020.

MOISÉS, M. Dicionário de termos literários. São Paulo: Cultrix, 12. ed., 2004.

MORE, T. A utopia. Trad. Maria Isabel Gonçalves Tomás. São Paulo: Martin Claret, 2. ed., 2010.

ORWELL, George. 1984. São Paulo: Companhia das Letras, 2009.

ORWELL, George. A revolução dos bichos. São Paulo: Companhia da Letras, 2007.

SWIFT, Jonathan. Viagens de Gulliver. Trad. Octavio Mendes Cajado. São Paulo: Publifolha, 1998.

TOLSTOY, Nikolai. A guerra secreta de Stálin. Trad. Aulyde Rodrigues. São Paulo: Círculo no livro, 1981.

Submissão: $20 / 04 / 2020$

Aceite: $02 / 07 / 2020$

https://doi.org/10.5007/2176-8552.2018n26p26

Esta obra foi licenciada com uma Licença Creative Commons Atribuição-NãoComercial 4.0 Internacional.

Universidade Federal de Santa Catarina - 2o Semestre de 2018 - 42 